\title{
The Development of Values Education in the Turkish High School Geography Curriculum
}

\author{
Bahaddin ŞAHIN 1 \\ Ministry of National Education, Ankara, TURKEY
}

${ }^{1}$ Dr.; Ministry of National Education, Board of Education, Ankara, TURKEY. bahaddinsahin[at] gmail.com. ORCID: 0000-00025911-1827

\begin{abstract}
In addition to providing knowledge and skills to individuals in the educational process, it is also aimed to attainment value and attitude. In this context, today, values are included in the curriculum of many countries around the world as a curriculum component. The aim of this research is to examine the geography course curriculum (GCC) applied in Turkey from the Republic to the present day with the dimension of values education. In this study, which is a qualitative research, descriptive content analysis method was used. All GCC's applied from 1924 to the present day constitute the universe of research. Since the entire research universe has been reached, no sample selection has been made. All GCC's that make up the research universe have been subjected to descriptive analysis. According to the results of the analysis, the research findings were presented in three periods: 1924-1971, 1971-2005 and 2005-2021. Accordingly, the GCC's applied between 1924 and 1971 do not include any content related to values education, while the GCC's applied between 1971-2005 included values implicitly in the general teaching purposes, and in the period 2005-2021, a curriculum element of values was included in the GCC. With the 2017 GCC, values were relationship with attainment, unit and class level for the first time. As a result, in the last half century, GCC's have shown slow but continuous development in terms of values education, but there are some problems in practice.
\end{abstract}

\section{Keywords}

Values Education, Curriculum, Geographical Education

To cite this article: Şahin, B. (2021). The Development of Values Education in the Turkish High School Geography Curriculum. Review of International Geographical Education (RIGEO), 11(2), 574-604. doi: 10.33403rigeo.885750 
Looking at human history, it seems that societies have created their own system of values for coexistence over a very long period of time. This created system of values is very important for the continuation of social existence and the culture of coexistence. For this reason, societies need to transfer the values they have to the next generations in various ways. At the beginning of these transfer routes in question is education.

Through education, individuals are tried to attainment the knowledge and skills they need in their future lives. However, it is aimed to attainment universal values along with the values of society experienced by individuals in the education process (Kalita, 2015). No individual is born with a set of values. In other words, values cannot be transferred from parents to children by genetic means (Venu, 2018; Kurtdede Fidan, 2019). Just like knowledge and skills, values are acquired later for individuals. These values and attitudes that appear as a result of values attainmented greatly shape the behaviors that a person will exhibit throughout their life, the decisions that they will make, and the choices that they will make (Knapp, 1972). These behaviors and decisions can affect not only the individual, but also the society to which the individual belongs and other societies to which he shares the same planet. For this reason, value transfer is extremely important in the educational process not only for the individual's own life cycle, but also for the healthy functioning of the social order at all spatial scales.

But the question of how to transfer values to subsequent generations has become more debatable, especially with the negative effects of rapid developments in science and technology from the last quarter of the twentieth century to the present day (Aslan \& Aybek, 2019). In addition, the belief that globalization makes consumerism, individualism and competition privileged causes concern in many countries, especially about how social values will be passed on to subsequent generations (Fu \& Chiu, 2007). Due to all these reasons, almost every country today openly or secretly places values and attitudes in its educational curriculums. As a matter of fact, Knapp (1972) notes that as for the place of values in educational curriculums, it is difficult and inefficient to prepare a quality curriculum without pre-evaluating some of the students ' attitudes and values.

It is seen that various international organizations working on education have also adopted an approach that puts values education at the center of the education process. For example, the report "OECD Future of Education and Skills 2030", prepared by the organization for Economic Development and cooperation (OECD", states the following statements regarding the importance of values education; "Strengthening and renewing trust in institutions and society and building more inclusive, just, sustainable economies and societies are committed to developing core values of common citizenship (respect, justice, personal and social responsibility, honesty and self-awareness) in school" (OECD, 2019).

In this context, the same report also emphasizes that values and attitudes are increasingly being included in educational curriculums of different countries around the world. Other international organizations, the United Nations International Children's emergency fund (UNICEF) with "Every Child Learns UNICEF Education Strategy 2019-2030, the report entitled" negotiation developed gradually from the earliest years of childhood, empathy, communication, 
participation values, such as it is stated that it will enable individuals to become equipped citizens by overcoming social, academic, economic and environmental challenges (UNICEF, 2019). As a result, all these reasons make studies related to values education quite common and important in educational sciences.

\section{Value and Attitude}

The concept of value education first appeared in the United States under the name Character Education at the beginning of the twentieth century (Demircioğlu and Tokdemir, 2008; Ulusoy, 2017). Towards the end of the twentyieth century, value and values education was often and directly addressed in studies related to Educational Sciences (Katılmış, 2017). Today, values education is up to date in Educational Sciences. But it is not possible to talk about a unity in the field about exactly what the values contain. Therefore, there are many different definitions related to the concept of value (Genç, 2019; Ulusoy and Dilmaç, 2018). According to Slater (2001), values are principles, ideals, standards, or life postures that guide general behavior and are reference points in decision-making or in the evaluation of beliefs and actions. According to Venkataiah (2002), values are a set of principles or standards of behavior. According to Shukla (2004), value can be defined as anything socially desired or desired that satisfies a human need, leading him to a higher ideal of life. According to Rokeach (1973), values are basic standards and judgments that represent common beliefs and thoughts that are considered necessary and appropriate by all individuals of society and aim to maintain the integrity of the social structure.

The OECD, an international organization that evaluates the knowledge and skills attainmented by students aged 15 through the PISA (Curriculumme for International Student Assessment), defines values as principles and beliefs that affect one's choices, judgments, behaviors and actions on the road to individual, social and environmental well-being (OECD, 2019). In this context, there is no definition accepted by everyone in the definition of value as a concept, and the same situation can be mentioned in the classification of values. But values in general in various studies; it is considered as scientific, economic, aesthetic, social, political and religious values (Genç, 2019; Lam, 1993).

One of the characteristics that are personality traits and should be distinguished by values is attitude. Attitudes can be defined as trends that regularly form the individual's thoughts, feelings and behaviors related to a psychological object (Demirhan İșcan, 2019). In other words, attitudes are the feelings, points of view, or views that individuals have about a subject (Roberts, 2003). For example, the expression" if I need to choose a profession attainment, I will prefer geography teaching attainment " should be considered as an expression of a person's attitude to geography teaching.

There are some fundamental differences between the concepts of value and attitude. Values are belief systems that drive behavior. In this sense, values are also determinants of attitudes. The manifestation of values is seen in the form of attitudes. In other words, attitudes determine how values arise in behaviors and thoughts (Edynbry, Hellyer \& Turner, 1977). It is extremely important that values are reflected in attitudes. But sometimes an individual's commitment to the values 
they believe in can manifest as different levels of attitudes. In addition, attitudes can change over time depending on certain factors, while values are much more rooted and persistent (Roberts, 2003).

Values and attitudes are openly or secretly included in the curriculum of almost all countries around the world. Looking at the responses of various countries to the Policy Questionnaire on Curriculum Redesign (PQC) survey conducted by the OECD, it seems that the values most included in educational curriculums are respect, empathy, honesty and flexibility (OECD, 2019).

\section{Approaches in Values Education}

Values are acquired in life, not innate to the individual. For this reason, how and how to attainment values for individuals in the education process is the subject of values education. In general, four basic approaches stand out in the process of values education. These approaches are the direct teaching of values approach, the value clarification approach, the value analysis approach and the moral dilemma approach (Aslan and Aybek, 2019; Yarar Kaptan, 2019). In a sense, these approaches show how to follow the path of values in the educational process. The direct teaching of values approach is the approach that involves transferring values directly to subsequent generations.

The value information approach is an approach that arises with the assumption that the direct teaching of values approach loses its importance and aims to make individuals understand the importance of these values by thinking about their own values that they have (Aslan and Aybek, 2019; Yarar Kaptan, 2019). Another approach, the value analysis approach, aims to enable individuals to use critical thinking and scientific research methods on value issues by using cognitive thinking steps in value education. In the approach to moral reasoning, the aim is to determine their moral judgments with stories presented to individuals and containing moral dilemmas (Akbaş, 2006; Yiğittir and Kaymakcı, 2012).

\section{Values in Geographical Education}

Looking at values education in the historical process, whether hidden or open, it seems that curriculum and education process always have a certain value base. In the same way, geographical education and teaching also includes a value dimension (Edynbry, Hellyer \& Turner, 1977). Even compared to many different disciplines, geography is one of the disciplines where value transfer can be best done. For this reason, it is widely accepted by geographical educators that value transfer is very important in geographical education (Lam, 1993; Hernando, 1998).

In this context, Wiegand (1986) states that values exist openly and secretly in the nature of geography and geographical education. According to Wiegand (1986), geographical education includes values that shape decisions that affect quality of life in a place. Values and attitudes are also effective in shaping the right decisions that people make. These values and attitudes are gained by understanding the problems with local, national and global perspectives through geographical education (Hong, 2018). 


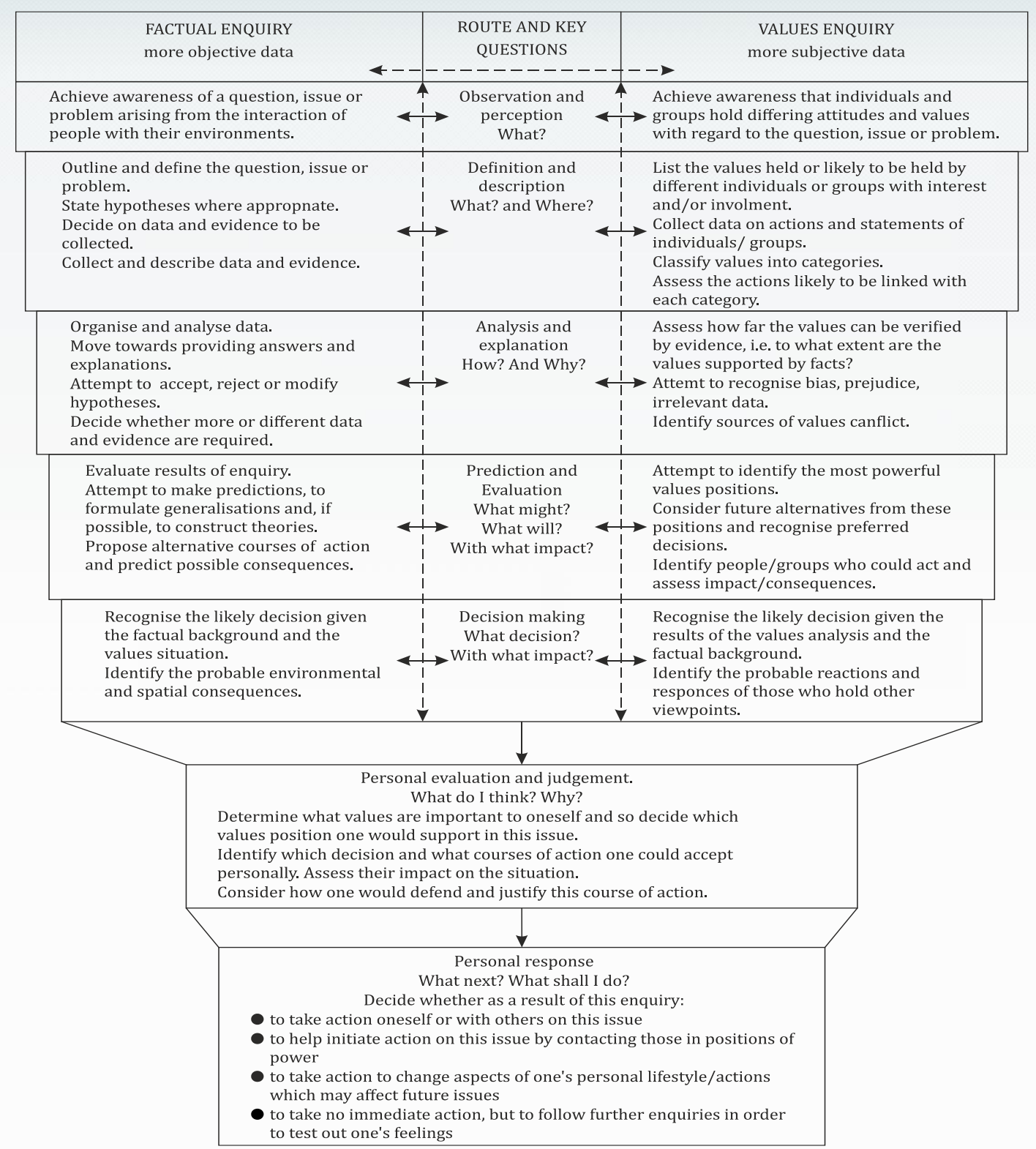

Figure 1. The route for geographical inquiry (Roberts, 2003).

Geographical skills are extremely important in attainmenting values and attitudes to individuals. In this context, geographical inquiry skill is very important especially in that it requires many other geographical skills (Artvinli, 2020). Geographical inquiry skills and the interaction of human beings and nature of this interaction and deforestation, soil erosion, excessive consumption of natural resources, pollution of the oceans, air pollution, overfishing, such as the movement of negative consequences can carry a lot of value for a sustainable world (Buttimer, 1974). However, it is possible to attainment attitudes and values such as social justice, perception of place and society, empathy and respect for differences for citizenship education through geographical questioning skills (Machon \& Walkington, 2000). In addition, geographical inquiry skills provide value analysis and value classification (Lambert \& Balderstone, 2002). Indeed, in Figure 1, the "school council 16-19 geography project" a geographic inquiry model developed within the scope of the route (the route for geographical correctly) viewed as a 
coordinated geographic inquiry question it is seen that the value can be performed with (Rawling, 2008; Roberts, 2003).

In this model, the value inquiry process performed together with geographical inquiry is carried out in seven steps: observation and understanding, identification and explanation, analysis and interpretation, prediction and evaluation, decisionmaking, personal evaluation and judgment, personal response. In this way, knowledge and skills as well as value can be transferred for any acquisition. In this context, Fien (1981) also states that value questioning is a comprehensive approach that integrates the best features of the various value strategies proposed by educators.

However, Lambert and Balderstone also created a similar framework for adapting different approaches to values education to school geography. According to the approach in question in Table-1, values in geographical education can be realized with 5 different approaches: value transfer, value analysis, moral reasoning, value explanation and action learning (Ref. Hopwood, 2008).

Table 1

Approaches to Values in Geographical Education

\begin{tabular}{ll}
\hline \multicolumn{1}{c}{ Approach } & \multicolumn{1}{c}{ Details } \\
\hline Values inculcation & Aims for pupils to adopt a pre-determined set of values \\
\hline Values analysis & $\begin{array}{l}\text { Pupils investigate and assess evidence which may support } \\
\text { value judgements }\end{array}$ \\
\hline $\begin{array}{l}\text { Growth of moral } \\
\text { reasoning }\end{array}$ & $\begin{array}{l}\text { Provides opportunities for pupils to discuss reasons for } \\
\text { adopting particular value positions }\end{array}$ \\
\hline Values clarification & $\begin{array}{l}\text { Helps pupils become aware of their own values in relation to } \\
\text { those of others }\end{array}$ \\
\hline Action learning & $\begin{array}{l}\text { Focuses on students having a reasoned base for whatever } \\
\text { actions they might take in relation to specific social or } \\
\text { environmental issues }\end{array}$ \\
\hline
\end{tabular}

Ref: Hopwood, 2008

Value transfer, as mentioned above, is inherent in geography and geographical education and is not new, unlike many disciplines (Slater, 2001). For example, Slater (1994), in a study with a group of teachers, asked teachers "what are the values in geography?" The question and reached the following answers: environmental care, human rights, social /political/economic justice, conformity to one culture/society, respect for other cultures, protection of landscape quality, use/explot/sustainability, lack of exploitation, empathy for Culture and the environment and responsibility to the environment.

Accordingly, geography teachers note that with geographical education, value transfer can be carried out not only on issues related to nature and nature, but also on social, political, economic-based issues. As a matter of fact, Roberts (2003) also states that the values that form the basis of attitudes on most geographical issues can be classified as social values, economic values, environmental values, and moral values. Fien (1996) argues that open-mindedness, respect for human rights, concern for justice, participation and commitment to sustainable development are values applicable to geographical education. 
The international geographical education declarations and declarations issued by the International geographical Union (IGU) Commission on geographical education (CGE) between 1992 and 2016 included the main values and attitudes that can be attainmented to individuals through geographical education. Accordingly, the IGUCGE declarations and declarations state that many values such as human rights, equality, and responsibility, love of nature and people, respect for cultural diversity, and sensitivity to the environment can be attainmented to individuals through geographical education (Table 2). Especially in the 1992 declaration on geographical education and the 2000 International Declaration on cultural diversity in geographyical education, it is seen that the values and attitudes that can be attainmented to individuals by geographical education are widely included (Artvinli and Kaya, 2010).

Table 2

International Geographical Union (IGU) Commission on Geographical Education (CGE) Values and Attitudes Contained In Declarations and Declarations of Geographical Education

\begin{tabular}{|c|c|}
\hline Charters and Declerations & Values and Attitudes \\
\hline $\begin{array}{l}1992 \text { International } \\
\text { Charter on Geographical } \\
\quad \text { Education }\end{array}$ & $\begin{array}{l}\text { - interest in their surroundings and in the variety of natural } \\
\text { and human characteristics on the surface of the Earth; } \\
\text { - appreciation for the beauty of the physical world, on the } \\
\text { one hand, and of the different living conditions of people, on } \\
\text { the other; } \\
\text { - concern for the quality and planning of the environment } \\
\text { and human habitat for future generations; } \\
\text { - understanding the significance of attitudes and values in } \\
\text { decision making; } \\
\text { - readiness to use geographical knowledge and skills } \\
\text { adequately and responsibly in private, professional and } \\
\text { public life; } \\
\text { - respect for the rights of all people to equality; } \\
\text { - dedication to seeking solutions to local, regional, national } \\
\text { and international problems on the basis of the "Universal } \\
\text { Declaration of Human Rights" }\end{array}$ \\
\hline $\begin{array}{l}2000 \text { International } \\
\text { Declaration on } \\
\text { Geographical Education } \\
\text { for Cultural } \\
\text { Diversity }\end{array}$ & $\begin{array}{l}\text { - the ability to be sensitive toward and defend human rights; } \\
\text { - an ability to understand, accept, and appreciate cultural } \\
\text { diversity; } \\
\text { - an ability to understand empathies and critique alternative } \\
\text { viewpoints about people and their social conditions; } \\
\text { - a willingness to be aware of the impact of their own } \\
\text { lifestyles on their local and broader social contexts; } \\
\text { - an appreciation of the urgent need to protect our } \\
\text { environment and bring about environmental justice to local } \\
\text { communities and regions that have experienced } \\
\text { environmental devastation; and } \\
\text { - An ability to act as an informed and active member of their } \\
\text { own and the global society. }\end{array}$ \\
\hline $\begin{array}{l}2007 \text { Lucerne Declaration } \\
\text { on Geographical } \\
\text { Education for Sustainable } \\
\text { Development }\end{array}$ & $\begin{array}{l}\text { - Dedication to seeking solutions to local, regional, national } \\
\text { and international questions and problems on the basis of the } \\
\text { "Universal Declaration on Human Rights". }\end{array}$ \\
\hline
\end{tabular}


SSahin, B. (2021). The Development of Values Education in the Turkish High School Geography....

\begin{tabular}{cl}
\hline $\begin{array}{c}\text { 2016 International } \\
\text { Charter on Geographical } \\
\text { Education }\end{array}$ & $\begin{array}{l}\text { - understand human relationships and their } \\
\text { responsibilitiesto both the natural environment and to } \\
\text { others. }\end{array}$ \\
\hline Ref: IGU-CGE, 1992; IGU-CGE, 2000; IGU-CGE, 2007; IGU-CGE, 2016
\end{tabular}

Looking at the Turkish literature, it seems that the number of studies that exist for values education in geographical education research is extremely limited. These studies are not about geographical and values education in a historical process, but rather about the current situation. Çifçi and Ünaldı (2014) have reached two important conclusions in their research in examining the views of geography teachers on values education. Accordingly, geography teachers share the opinion that there are not enough explanations for values education in the geography course curriculum (GCC). However, geography teachers also express the view that they do not receive adequate training for values education during their undergraduate education. A similar result is seen in the study Katılmış and Balcı (2017). Accordingly, in the relevant research, candidates for geography teachers concluded that they do not have sufficient education in relation to values education.

Değirmenci (2018), 2017 GCC values education in a survey that examined in terms of the size of GCC 2005 to 2017, according contains important developments in the positive direction, but the curriculum relationship with the curriculum content is not of the values in a balanced distribution of wealth. Aydın and Yaşar (2020) compared secondary geography textbooks written according to GCC in 2005 and 2017 according to their approach to values education. Accordingly, in Geography textbooks, direct teaching of values (indoctrination) approach and value explanation (value clarification) approaches are widely used. These studies, which deal with values education in the dimensions of geography teachers, geography teacher candidates, GCC and geography textbooks, can be said to have important problems in each research dimension when evaluated as a whole.

\section{Purpose of the Research}

Values are included in the curriculum of many countries around the world as a curriculum component. In Turkey, it is possible to see traces of values as open or hidden in the educational curriculums implemented since the Republic (Beldağ, 2019). Between 1924 and 2021 in Turkey, the GCC underwent changes many times. Very few of these changes involve drastic changes, while most of them involve smallscale updates. However, in this process, there is no research in the field regarding how and how values are included in GCC. This research is designed to fill this gap and the aim of the research is to examine the secondary education GCC's applied in Turkey between 1924-2021 with the dimension of value education. Research questions for this purpose include;

1. What values are included in the GCC's applied between 1924-2021?

2. How are the values related to unit, acquisition and class level in GCC's applied between 1924-2021? 


\section{Methodology}

\section{Research Process}

Descriptive content analysis, which is one of the qualitative research approaches, was preferred in this study, which aims to examine GCC's applied between 19242021 with the dimension of value education. Descriptive content analysis "to describe general trends and specific research in a discipline and the description is aimed at a systematic review of the results of the research" (Çalık \& Sözbilir, 2014) Descriptive content analysis the data obtained previously identified are summarized and interpreted according to the themes (Yıldırım and Şimşek, 2016). The purpose of using descriptive content analysis in research is to present research findings in an edited and interpreted format.

\section{Source of the Data}

From the declaration of the Republic in Turkey to the present day, geography at the level of secondary education has existed as an imperative and independent course, despite sometimes-reduced course hours. In this context, the data sources of the research constitute the curriculum of 17 geography courses applied at the secondary level between 1924-2021 (Table 3).

Table 3

GCC's Implemented Between 1924-2021

\begin{tabular}{llllll}
\hline & GCC & Years & & GCC & Years \\
\hline 1. & 1924 GCC & $1924-1927$ & 10. & 1983 GCC & $1983-1992$ \\
\hline 2. & 1927 GCC & $1927-1938$ & 11. & 1992 GCC & $1992-2005$ \\
\hline 3. & 1938 GCC & $1938-1940$ & 12. & 2005 GCC & $2005-2010$ \\
\hline 4. & 1940 GCC & $1940-1942$ & 13. & 2010 GCC & $2010-2011$ \\
\hline 5. & 1942 GCC & $1942-1957$ & 14. & 2011 GCC & $2011-2014$ \\
\hline 6 & 1957 GCC & $1957-1971$ & 15. & 2014 GCC & $2014-2017$ \\
\hline 7. & 1971 GCC & $1971-1973$ & 16. & 2017 GCC & $2017-2018$ \\
\hline 8. & 1973 GCC & $1973-1982$ & 17. & 2018 GCC & $2018 \ldots \ldots$. \\
\hline 9. & 1982 GCC & $1982-1983$ & & & \\
\hline
\end{tabular}

\section{Data Collection}

The data used in the research was collected using the document review technique in accordance with the document review method. At the first stage, most of the secondary education GCC's were reached by surveying the e-archive covering the issues between 1926-2021 of the Ministry of National Education (MoNE) Tebliğler Journal and surveying the issues of the communiqué Journal published between the relevant dates. In the second phase, Secondary Education GCC's applied between 1924-2021 were provided in taranak archive of the presidency of the Board of Education. Thus, all of the GCC's applied in secondary education and included in the research were reached. Finally, in the third stage, the authenticity and accuracy of the data were checked by comparing the GCC's obtained through both the board of education and the Journal of Tebliğ (Figure 2). 
SSahin, B. (2021). The Development of Values Education in the Turkish High School Geography....

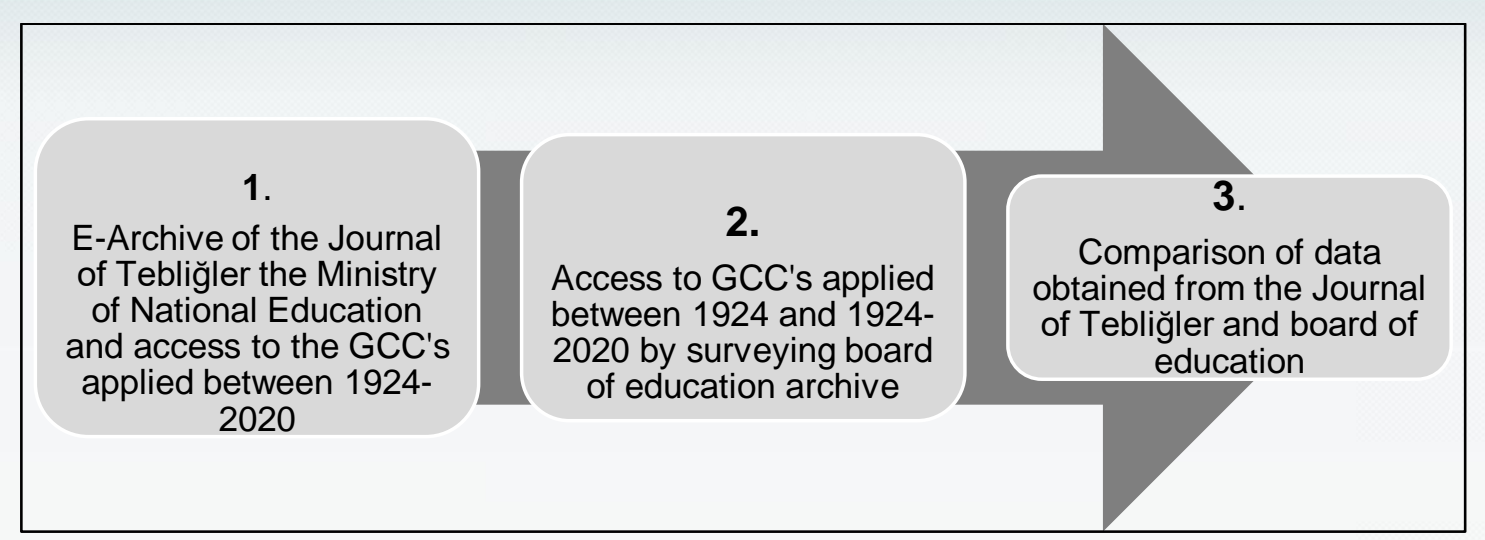

Figure 2. Data collection and control stages

\section{Data Analysis}

The descriptive content analysis form in Table-4 was created to examine the GCC's that make up the data set of the research and were applied between 1924 and 2021. Descriptive content analysis data obtained from GCC's were categorized and analyzed through the data form. Accordingly, three main categories were formed. These categories are GCC's applied in the period 1924-1971, GCC's applied in the period 1971-2005 and GCC's applied in the period 2005-2021. As a criterion for categorizing data, the size in which values and values education are included in GCC's was taken into account. Accordingly, there is no content related to values education in the GCC's implemented between 1924 and 1971. In the GCC's implemented between 1971-2005 periods, implicit content related to values is included in the general objectives of the curriculum. Finally, in the GCC's implemented between 2005-2021, values are both within the overall aims of the curriculum and as a component of the curriculum. Research findings were accessed through these data, which are categorized as a result.

Table 4

Descriptive Content Analysis Data Form Used in Data Analysis

\begin{tabular}{|c|c|c|c|c|c|}
\hline \multirow{2}{*}{ GCC } & & \multirow{2}{*}{$\begin{array}{l}\text { Values } \\
\text { Included in the } \\
\text { General } \\
\text { Objectives of } \\
\text { the GCC }\end{array}$} & \multicolumn{3}{|c|}{$\begin{array}{c}\text { Values Contained in the Content } \\
\text { Size of the GCC }\end{array}$} \\
\hline & Tears & & Grade & Unit & Attainment \\
\hline
\end{tabular}

\section{Validity and Reliability of the Research}

In qualitative research, reporting the data collected during the research process and explaining how the researcher reached the results are important criteria for the validity of the research (Yıldırım \& Şimşek, 2018). In order to ensure the internal validity of the research, the descriptive content analysis data form developed at the beginning of the research was examined by an independent researcher specializing in geographical education and the data form was given its final version by making the necessary arrangements according to the feedback received. In order to ensure the external validity of the research, all GCC's from the Republic to the present day 
have been examined and detailed explanations of the research steps and method have been given. Reliability in qualitative research also means consistency of the researcher's approach from the point of view of different projects and different researchers (Creswell, 2013). The reliability of the research and data is ensured by confirming the results of the research and providing the data directly in a descriptive manner.

\section{Findings}

The findings from the research data were given in three periods: 1924-1971, 1971-2005 and 2005-2021.

\section{Values of Geography Curriculum in 1924-1971 Period}

During the period 1924-1971, six curriculum changes were made for secondary geography courses: 1924, 1927, 1938, 1940, 1942 and 1957. Among these, the longest-lasting curriculum was the first, which was implemented in 1941. It is a 1942 GCC's prepared in accordance with the decisions of the Turkish Geographical Congress (Geçit, 2008). The most basic feature of the six GCC's implemented during this period is that they consist of lists of topics that are expected to be learned by students. For this reason, GCC's implemented during this period are largely knowledge-oriented and partially skill-oriented. So much so that none of these educational curriculums even include the general aims of the curriculum. Therefore, no findings on values and values education were found in GCC's applied in the period 1924-1971.

\section{Values of Geography Curriculum in 1971-2005 Period}

During the period 1971-2005, five curriculum changes were made for secondary geography courses, including 1971, 1973, 1982, 1983 and 1992. As in the previous period, GCC's applied in this period are in the form of lists of topics that students are expected to learn in the context of content. But unlike the period 1924-1971, this period also included the general aims of teaching geography in GCC's. Therefore, this is the most important difference that distinguishes GCC's applied between 19712005 period from GCC's applied during 1924-1971 period. In these general educational purposes, values and values education is not referred to by this nomenclature, but the values and attitudes that are intended to be attainmented to students by teaching geography, albeit implicit, are also emphasized.

Geography curriculum in 1971. The first curriculum implemented in this period, is a draft curriculum, but it is the first curriculum to include the aims of geography teaching. 1971 GCC contains five general objectives related to the teaching of geography. 4 of these 5 generals aims also implicitly include the values that students want to attainment through geographical education (Table 5). Accordingly, 1971 GCC aims to provide students with values and attitudes such as savings, love of nature, efforts to solve local and global problems, responsibility for cultural and economic development, assistance with different cultures, understanding peace and cultural diversity through geographical education (Table $5)$. 
SSahin, B. (2021). The Development of Values Education in the Turkish High School Geography....

Table 5

General Objectives of the GCC with Value 1971

\begin{tabular}{l}
\hline \multicolumn{1}{c}{ General Objectives of the GCC with Value 1971} \\
\hline $\begin{array}{l}\text { It recognizes the conditions and possibilities of the earth as } \\
\text { the habitat of humanity. It knows that these possibilities are }\end{array}$ \\
not unlimited. For this reason, it understands that it is Saving, love of nature \\
necessary to avoid their waste and makes it a habit. It loves \\
nature and protects.
\end{tabular}

It understands that Inter-national assistance and understanding are essential and necessary for the protection and prosperity of our own existence, and that the path of interest in every business is peace and

Cooperation with

different cultures, peace understanding.

By seeing the results of other nations ' country conditions, lives, various problems and efforts to solve these problems, he understands that high culture and scientific work prepare the possibility for a successful life in all kinds of conditions. In this way, he gets into the habit of constantly

Understanding cultural diversity progressing in this direction.

Ref: MoNE, 1971

Geography curriculum in 1973. In 1973 GCC, different from 1971 GCC, separate objectives were included for each course in relation to General Geography, Geography of countries and Geography of Turkey, as well as the general objectives of Geography Teaching (Geçit, 2008). In this context, the 1973 GCC contains 20 aims related to the teaching of geography. Seven of these aims cover the values that students want to attainment through Geographical Education. Accordingly, the number of teaching objectives containing value in the 1973 GCC is greater than in the 1971 GCC. In addition to the values contained in the general objectives of the 1971 GCC, the 1973 GCC also includes values such as patriotism and conservation of natural and cultural heritage/resources (Table 6).

Table 6

General Aims of the GCC with Value 1973

\begin{tabular}{ll}
\hline General Objectives of the GCC with Value 1973 & \multicolumn{1}{c}{ Values } \\
\hline $\begin{array}{l}\text { Starting from the near circle, to know our country and the } \\
\text { world; to make the students ' love of homeland, nation and } \\
\text { humanity more conscious, more rooted. }\end{array}$ & Patriotism, human love \\
\hline $\begin{array}{l}\text { It is important to understand that a common opinion and effort } \\
\text { are needed in solving the problems of the country and the }\end{array}$ & $\begin{array}{l}\text { To endeavour for } \\
\text { country and world } \\
\text { problems, }\end{array}$ \\
$\begin{array}{l}\text { world, to recognize that all nations and all individuals of the } \\
\text { nation, and in the meantime, themselves, will carry heavy } \\
\text { responsibilities in cultural and economic development. }\end{array}$ & $\begin{array}{l}\text { responsiltural and economic } \\
\text { development }\end{array}$ \\
\hline
\end{tabular}


By showing, the country's conditions, life, various problems and their efforts to solve these problems and their results, understanding that advanced culture and scientific work allow a successful life, so that they have a habit of continuous progress in this direction.

Giving the belief that the help and understanding that will be provided in this way is necessary for the protection of our own existence and for our well-being by providing an accurate view and understanding of international groupings.

Educating students as citizens who believe in the need to protect and evaluate our national resources of wealth and have attainmented habits along this path.

Understanding cultural diversity

Cooperation with
different cultures,
peace, conservation of
natural and cultural
heritage/resources
Cooperation with
different cultures,
peace, conservation of
natural and cultural
heritage/resources

Ensuring that students are intellectual citizens who lean on the problems of our country and our nation, study and learn flour in a fundamental way, participate in the work to solve these

Patriotism problems for the benefit of the country and the nation.

Students, the Turkish nation within the family of nations, the situation of Turkey within the countries, to properly understand and give them the awareness of citizenship, which will take responsibility for the development of our country.

Ref: MoNE, 1973

Geography Curriculum in 1982. After nine years of implementation, the 1973 GCC underwent a minor change and the 1982 GCC began to be implemented. But the 1982 GCC was implemented in a short period of time, such as one year, although it was a temporary curriculum. The teaching objectives, which were also given separately according to the courses in the 1973 GCC, were given in the 1982 GCC in general in nine objectives. Of these nine general aims, only two are of value, and both aims emphasize patriotism. Accordingly, the values such as saving, love of nature, striving for country and world problems, understanding cultural diversity, peace, responsibility, which are included in the general educational aims of the 1971 and 1973 GCC, are not included in the 1982 GCC (Table 7).

Table 7

GCC's General Objectives with Value 1982

\begin{tabular}{lc}
\hline GCC's General Objectives with Value 1982 & Values \\
\hline To introduce our country and our compatriots to students starting & \\
from their close environment to make their feelings of nationality, & Patriotism \\
homeland and humanity more conscious and more rooted. & \\
\hline
\end{tabular}

By examining the mutual relations of people with each other and their geographical environment, the ways of living in human communities and the ways of living, ensuring that students grow

Patriotism up as useful elements in the economic development of the hostel.

Ref: MoNE, 1982 
Geography Curriculum in 1983. The 1982 GCC was revised after one year of provisional implementation and adopted by the board of education as the 1983 GCC with some minor changes. It is also possible to see these changes made on the 1982 GCC on the overall objectives of the 1983 GCC. As a matter of fact, the number of general objectives increased from nine in the 1982 GCC to thirteen in the 1983 GCC. Seven of these thirteen objectives include patriotism, human love, saving, love of Nature, Conservation of natural and cultural heritage/resources, and peace values (Table 8). In this aspect, it can be said that the 1983 GCC was a more value-oriented curriculum than the 1982 GCC, and that it largely included the values contained in the 1971 and 1973 GCC. But in the 1983 GCC, as in the 1982 GCC, the value of patriotism is at the forefront in general purposes. So much so that four of the seven general aims that contain value directly emphasize the value of patriotism (Table 8).

Table 8

General Objectives of the 1983 And 1992 GCC with Value

General objectives of the 1983 and 1992 GCC with value Values

To introduce our country and the world starting from their close circles; to make their love of homeland, nation and humanity more conscious and more rooted in them.

Patriotism, human of love

By stating the place and importance of Turkey in the world and in them to develop a sense of responsibility for the development of our Patriotism country.

By examining the mutual relations of people with each other and their geographical environment, the places of life of human communities and the ways of living, to ensure that they grow up as

Patriotism useful elements in the economic development of our country.

The earth as a human habitat conditions, opportunities and resources to introduce this opportunity and the resources are not unlimited, so that you should avoid wasting them understand; and love of nature protection habits.

To understand that nations need each other and are obliged to cooperate with each other; that their common problems can be solved with mutual goodwill and efforts.

Ensuring that students grow up as citizens who believe in the need to protect and evaluate our national resources of wealth and have acquired habits along this path.

To educate students as intellectual citizens who lean on the problems of our country and our nation, study and learn them and sincerely participate in the solution of these problems for the

Saving, love nature benefit of the country and the nation.

Ref: MoNE, 1983

Geography Curriculum in 1992. 1983 GCC, after nearly nine years of implementation, changed the curriculum attainment in 1992. The 1992 GCC included minor changes in the content of some courses. Looking at the general teaching objectives of the 1992 GCC, it seems that all teaching objectives are the same as the 1983 GCC (Table 8). The 1992 GCC was implemented until 2005. Therefore, in the twenty-two years between 1983-2005, there was no change in 
values in the GCC. As a result, it can be said that patriotism is the most effective value that students want to attainment by teaching geography in the period 1971-2005.

\section{Values of Geography Course Curriculum in 2005-2021 Period}

During this period, six GCC changes were carried out in 2005, 2010, 2011, 2014, 2017 and 2018. The main difference between the GCCS implemented in this period and the GCCS implemented in the 1971-2005 period in the context of values education is that the values are included as an element of the curriculum. However, as with the GCCS implemented in the 1971-2005 period, values were strongly emphasized in the overall aims of the GCCS during this period.

Geography curriculum in 2005. The 2005 GCC, the first curriculum implemented during this period, can also be seen as the GCC, which includes the most radical changes from the republic to the present day (Geçit, 2008). One of the drastic changes in question is the value education dimension of the 2005 GCC. Values education in GCC's implemented in Turkey was first included in the 2005 GCC as a curriculum element under this name (Karabağ and Şahin, 2007). In 2005 GCC, values education was included under the heading "values and attitudes" and ten different values were included: unity, tolerance, science, love, respect, sensitivity, patriotism, peace, aesthetics and responsibility (MoNE, 2005). However, within the general objectives of the curriculum 5, 6, 7, 9 and thirteen direct reference to values in articles (MoNE, 2005) (Table 9). Looking at these articles, it is value noting that these articles are partially similar to the values and attitudes contained in the international declarations and declarations on geographical education contained in Table-2.

Table 9

GCC Items Related with Values for the General Purposes of the 2005

Items on Values Education

5. Develops a sense of ownership of spatial values (what nature and human produce and accumulate) belonging to his country and the world, starting from his immediate environment.

6. Develops awareness of responsibility for the functioning of the ecosystem.

7. Develops "consciousness saving" in the use of human and natural resources by understanding the importance of spatial planning for the harmonious coexistence and continuity of the values produced by nature and human systems.

9. Understands the importance of harmonizing development processes with nature.

13. Assimilates the importance of geographical values in the acquisition of "consciousness homeland".

Ref: MoNE, 2005

Another title cited in the 2005 GCC was "vision and principles of the curriculum". The articles contained in the vision and principles of the curriculum regarding values are included in Table-10. As can be seen in Table-10, the sections in question show proper and effective use of space, homeland integrity and commitment to national values, carrying nature and human values into the future, sensitivity to nature and human interaction, emphasis on consciousness saving (MoNE, 2005). 
SSahin, B. (2021). The Development of Values Education in the Turkish High School Geography....

Table 10

Items on Values in the 2005 GCC's Vision and Principles

\begin{tabular}{ll}
\hline \multicolumn{1}{c}{$\begin{array}{c}\text { Articles belonging to the vision of the } \\
\text { curriculum and related to Values } \\
\text { Education }\end{array}$} & $\begin{array}{c}\text { Articles belonging to the vision of the } \\
\text { curriculum and related to Values Education }\end{array}$ \\
$\begin{array}{l}\text { Using place correctly and effectively by } \\
\text { understanding the elements of nature and } \\
\text { human, }\end{array}$ & $\begin{array}{l}\text { The knowledge, skills, attitudes and values } \\
\text { that the curriculum aims to attainment are } \\
\text { portable to life through the daily and } \\
\text { professional lives of students. }\end{array}$ \\
\hline $\begin{array}{l}\text { Considering the future by giving } \\
\text { importance to the quality of the } \\
\text { environment, committed to national } \\
\text { values, protecting the homeland, }\end{array}$ & $\begin{array}{l}\text { The curriculum has a content that is } \\
\text { sensitive to nature and human interaction, } \\
\text { aims to develop in harmony with nature and } \\
\text { encourages saving. }\end{array}$ \\
\hline $\begin{array}{l}\text { Sense of responsibility for the protection } \\
\text { of the world and humanity, }\end{array}$ & $\begin{array}{l}\text { The curriculum is sensitive to Turkey's } \\
\text { positional importance, homeland integrity } \\
\text { and national values. }\end{array}$ \\
\hline $\begin{array}{l}\text { It is to educate individuals who develop } \\
\text { and implement strategies to carry the } \\
\text { values of nature and human Into the future } \\
\text { by using geographical knowledge and } \\
\text { skills. }\end{array}$ & \\
\hline
\end{tabular}

Ref: MoNE, 2005

However, despite the emphasis on values in the 2005 GCC introduction section, the ten values included in the curriculum were not relationship with attainments (Şahin, 2019). In other words, what value is given in which learning area, what attainment and what grade levels are not included in the curriculum. Therefore, it is seen that how the value-learning area, value-acquisition and value-class level relationship will be in the implementation of the curriculum is completely left to the curriculum practitioners.

However, in the 2005 GCC, the lack of an adequate explanation of the size of values is seen as a deficiency. In this context, in a study entitled "opinions and thoughts of geography teachers about the current state of values education" conducted by Çifçi and Ünaldı (2014), most geography teachers expressed the opinion that there are not enough explanations about values in the curriculum. 2005 GCC; Although changes were made at various scales in 2010, 2011 and 2014, there were no changes in the size of the curriculum's values training and the values included in the curriculum (MoNE, 2010; MoNE, 2011; MoNE, 2014).

Geography Curriculum in 2017. By 2017, the GCC change was carried out attainment. With the 2017 GCC, the curriculum's content size as well as its values education size have changed. A press release made by board of education on July 18, 2017 shows that values and values education constitute the main focus of educational curriculums (Board of Education, 2017). It is possible to see the same expression in other countries ' teaching curriculums. For example, in Singapore, the philosophy of teaching curriculums is stated that teaching curriculums are focused on values and Character Development (Ministry of Education, Singapore, 2018). 
Looking at the general objectives of the 2017 GCC, it is seen that 5 articles related to the values contained in Table- 9 and belonging to the 2005 GCC are included in the same way. In the 2017 GCC, a total of 10 values: justice, friendship, honesty, selfcontrol, patience, respect, love, responsibility, patriotism and benevolence were included under the heading "values". But these values are not only specific to the GCC, but also include the same values in all updated curriculum. However, another important point is that, unlike the 2005 GCC, the curriculum also includes attitudes and behaviors that are expected to be acquired by students in relation to each value (MoNE, 2017) (Table 11).

Table 11

Attitudes and Behaviors Related To Values and Values Included In the 2017 Geography Course Curriculum

\begin{tabular}{|c|c|}
\hline Values & Attitudes and behaviors relationship with values \\
\hline Justice & To be fair, to be equal, to share \\
\hline Friendship & Trust, be loyal, be loyal, help \\
\hline Honesty & Be clear, be truthful, act ethically, be reliable, keep your word \\
\hline Self-Control & $\begin{array}{l}\text { Control their behavior, take responsibility for their behavior, have self- } \\
\text { confidence }\end{array}$ \\
\hline Patience & Be persistent, endure \\
\hline Respect & $\begin{array}{l}\text { Being humble, treating others the way it wants them to be treated, } \\
\text { valuing other people's personalities }\end{array}$ \\
\hline Love & Caring for family unity, making sacrifices \\
\hline Responsibility & Being responsible to yourself, environment, homeland, family \\
\hline Patriotism & $\begin{array}{l}\text { Being hardworking, solidarity, complying with rules and laws, being } \\
\text { sensitive to historical and natural heritage, caring about society }\end{array}$ \\
\hline Helpfulness & $\begin{array}{l}\text { To be generous, to be altruistic, to cooperate, to be compassionate, to } \\
\text { be hospitable, to share }\end{array}$ \\
\hline
\end{tabular}

Ref: MoNE, 2017

Looking at Table-12, it is seen that only four of the 10 values (responsibility, patriotism, love and respect) included in the 2017 GCC are the values included in the GCC (2005, 2010, 2011 and 2014 GCC) implemented between 2005 and 2017. The values of solidarity, tolerance, science, sensitivity, peace and aesthetics were not included in the 2017 GCC. Accordingly, the values included in the 2017 GCC appear to have changed significantly compared to the GCCS implemented in 2005 and beyond (Değirmenci, 2018).

Table 12

Comparison of GCC's Implemented Between 2005-2017 And Values included in the 2017 GCC

\begin{tabular}{ll}
\multicolumn{1}{c}{$\begin{array}{c}\text { Values included in the 2005, 2010, } 2011 \\
\text { and 2014 GCC }\end{array}$} & \multicolumn{1}{c}{ Values Included in the 2017 GCC } \\
\hline 1.Respect & 1.Respect \\
\hline 2.Love & 2.Love \\
\hline 3.Responsibility & 3.Responsibility \\
\hline 4.Patriotism & 4.Patriotism \\
\hline 5. Solidarity & 5.Justice \\
\hline 6.Tolerance & 6.Friendship \\
\hline 7.Science & 7.Honesty \\
\hline 8.Sensivity & 8.Patience \\
\hline 9.Peace & 9.Self-Control \\
\hline
\end{tabular}


SSahin, B. (2021). The Development of Values Education in the Turkish High School Geography....

\begin{tabular}{l} 
10.Esthetic \\
\hline Ref: MoNE, 2005; MoNE, 2010; MoNE, 2011; MoNE, 2014; MoNE, 2017
\end{tabular}

The biggest change in the value size of the 2017 GCC compared to previous GCCS is that the values are relationship with the content size of the curriculum. All ten values included in the 2017 GCC are relationship by grade level with the units and achievements that make up the content size of the curriculum (Şahin, 2019).

The 2017 GCC consists of 4 units:" Natural Systems "," Human Systems "," Global Environment: Regions and Countries "and" Environment and society " (MoNE, 2017). By placing the values contained in the Curriculum under each unit, the relationship between the values and the units is achieved. Accordingly, the unit with the highest value relationship is "natural systems", while the unit with the least is "global environment: regions and countries". Looking at the distribution of values by units, love of nature, responsibility, self-control and benevolence in the "natural systems" unit; "Human systems" in the unit, friendship, honesty, respect, selfcontrol, patriotism and helpfulness; "the Global Environment: Regional and Country" in the unit justice, respect, and patriotism; "Environment and Society" for the unit to work in nature, love, patience, responsibility and self-control values is given. (Figure 3).

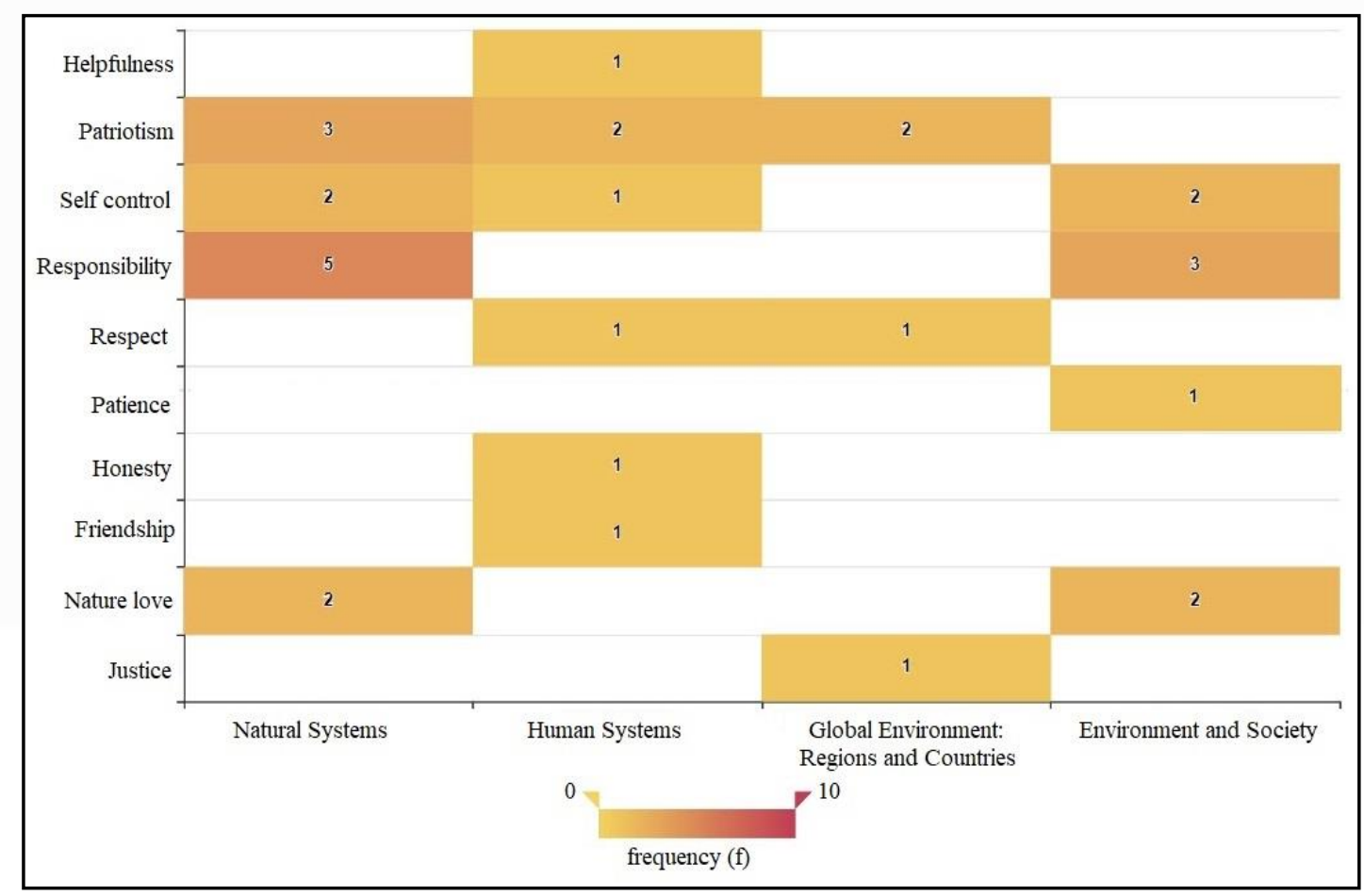

Figure 3. GCC's Value-Unit Relationship 2017 (MoNE, 2017)

As shown in figure 3, there are no values contained in all units. Only patriotism value was included in three units:" natural systems "," human systems "and "Global Environment: countries and regions", while other values could be included in no more than two units. As a result, it can be said that in the 2017 GCC, values did not show a homogeneous distribution by unit. Looking at the value-attainment relationship of the 2017 GCC, it is seen that a total of 31 value - attainment 
relationship has been made. However, the number of wins relationship is 23 (table 13). The reason for this is that some attainments are relationship with more than one value. Accordingly, 9.1.1 attainment two, 9.4.2 attainment two, 10.1.14 attainment 2, 10.2.9 attainment 2, 10.4.4 attainment 2, 11.1.1 attainment 3 and 11.1.4 attainment two were relationship with the value in the curriculum (table 13). Considering that the total number of attainments in the curriculum is 130 , it is understood that the attainment rate containing the value is \%17.69. The number of attainments not relationship with values is 107. In this context, it seems that the extensive majority of attainments are not relationship with values, and the valueattainment relationship is limited. As a result, in the 2017 GCC, it can be said that the value-attainment Relationship does not show a homogeneous distribution, as in the value-unit Relationship.

Table 13

Value-attainment relationship GCC at the 2017

\begin{tabular}{|c|c|c|}
\hline Value & Grade & Attainments relationship with values \\
\hline \multirow{4}{*}{ Nature Love } & 9 & 9.1.1. Explain nature and human interaction with examples. \\
\hline & 9 & $\begin{array}{l}\text { 9.4.2. Evaluates changes caused by human influence in the } \\
\text { natural environment in terms of their results. }\end{array}$ \\
\hline & 11 & $\begin{array}{l}\text { 11.1.1. Explain the factors that are effective in the formation } \\
\text { and reduction of biodiversity. }\end{array}$ \\
\hline & 12 & 12.4.1. Explain the limitations of the natural environment. \\
\hline \multirow{5}{*}{ Self-Control } & 9 & 9.1.1. Explain nature and human interaction with examples. \\
\hline & 9 & $\begin{array}{l}\text { 9.4.2. Evaluates changes caused by human influence in the } \\
\text { natural environment in terms of their results. }\end{array}$ \\
\hline & 11 & $\begin{array}{l}\text { 11.1.1. Explain the factors that are effective in the formation } \\
\text { and reduction of biodiversity. }\end{array}$ \\
\hline & 11 & $\begin{array}{l}\text { 11.4.7. Evaluates the sustainable use of Natural Resources in } \\
\text { terms of recycling strategies. }\end{array}$ \\
\hline & 12 & $\begin{array}{l}\text { 12.2.2. Interprets the relationship between urbanization, } \\
\text { migration and industrialization in terms of their social effects. }\end{array}$ \\
\hline \multirow{7}{*}{ Patriotism } & 9 & $\begin{array}{l}\text { 9.2.4. Distinguishes settlements in Turkey according to their } \\
\text { administrative functions. }\end{array}$ \\
\hline & 10 & $\begin{array}{l}\text { 10.1.14. Assesses the use of Turkish territory in terms of } \\
\text { productivity. }\end{array}$ \\
\hline & 10 & $\begin{array}{l}\text { 10.1.17. Analyzes the distribution of natural plant } \\
\text { communities in Turkey in terms of growing conditions. }\end{array}$ \\
\hline & 11 & $\begin{array}{l}\text { 11.1.4. Explain the elements and functioning of the aquatic } \\
\text { ecosystem. }\end{array}$ \\
\hline & 11 & $\begin{array}{l}\text { 11.3.4. Assesses the fact that Turkey has been a center of } \\
\text { civilizations throughout history in terms of its location. }\end{array}$ \\
\hline & 12 & $\begin{array}{l}\text { 12.2.14. Explains the relationship of natural and cultural } \\
\text { symbols in Turkey with space. }\end{array}$ \\
\hline & 12 & $\begin{array}{l}\text { 12.3.3. Assesses Turkey's geopolitical location in the historical } \\
\text { process. }\end{array}$ \\
\hline \multirow{3}{*}{ Responsibility } & 10 & $\begin{array}{l}\text { 10.1.11. Assesses the economic, social and cultural effects of } \\
\text { efficient use of water in Turkey. }\end{array}$ \\
\hline & 10 & $\begin{array}{l}\text { 10.1.14. Assesses the use of Turkish territory in terms of } \\
\text { productivity. }\end{array}$ \\
\hline & 10 & 10.4.4. Explain disaster prevention methods. \\
\hline
\end{tabular}


11.1.1. Explain the factors that are effective in the formation and reduction of biodiversity.

11.1.4. Explain the elements and functioning of the aquatic ecosystem.

11.4.3. Analyzes the use of non-renewable resources in terms of depletion and alternative resources.

12.1.2. It makes future inferences about changes in natural systems.

12.4.2. Compares the policies and practices of countries with

12 different levels of development to prevent environmental problems.

\begin{tabular}{lcl} 
& \multicolumn{2}{c}{ problems. } \\
\cline { 2 - 3 } Friend & 10 & $\begin{array}{l}\text { 10.2.8. It draws conclusions about the causes and } \\
\text { consequences of migrations around the world using historical } \\
\text { texts, documents and maps. }\end{array}$ \\
\cline { 2 - 3 } Respect & 10 & $\begin{array}{l}\text { 10.2.9. Evaluates migrations in Turkey in terms of causes and } \\
\text { consequences. }\end{array}$ \\
Helpfulness & 11 & $\begin{array}{l}\text { 11.3.2. Explain the factors affecting the spread of different } \\
\text { cultural regions on Earth. }\end{array}$ \\
\cline { 2 - 3 } Honesty & 10 & $\begin{array}{l}\text { 10.2.9. Evaluates migrations in Turkey in terms of causes and } \\
\text { consequences. }\end{array}$ \\
Justice & 12 & $\begin{array}{l}\text { 12.2.11. Explains the effects of Trade Centers in Turkey on } \\
\text { tradable products and flow directions. }\end{array}$ \\
Patience & 12 & $\begin{array}{l}\text { 12.3.11. It links the spatial elements that create problems } \\
\text { between countries with today's conflict areas. }\end{array}$ \\
\cline { 2 - 3 } & 10 & \begin{tabular}{l} 
10.4.4. Explain disaster prevention methods. \\
\hline
\end{tabular}
\end{tabular}

Ref: MoNE, 2017

when looking at the distribution of attainments in the 2017 GCC by grade level, which are relationship with any value. it can be seen that the acquisition includes 3 values at the grade level, 5 at the tenth-grade level, 7 at the eleventh-grade level and 8 at the twelfth-grade level (Figure 4). As mentioned earlier, some of these attainments have been relationship with more than one value. For example, at the ninth-grade level, the number of attainments relationship with the value is three, while the total value Relationship is five.

The class levels with the highest number of attainments containing values are 12 and 11, respectively. Acquisition-value 15 relationships were made at the eleventh and twelfth grade levels. Considering that the number of attainments containing value throughout the curriculum is 23 , it is value noting that this number is quite high. However, geography courses are taught as elective at eleventh and twelfth grade levels. Therefore, given the students who do not choose a geography course at these grade levels, it can be said that this will negatively affect the transfer of value in the geography course. In the ninth and tenth grade levels, where the geography course is mandatory, there are a total of 56 achievements. But only 8 attainment value relationships were made at the ninth and tenth grade levels. Given attainments that contain more than one value at these class levels, the total value Relationship appears to be thirteen. 


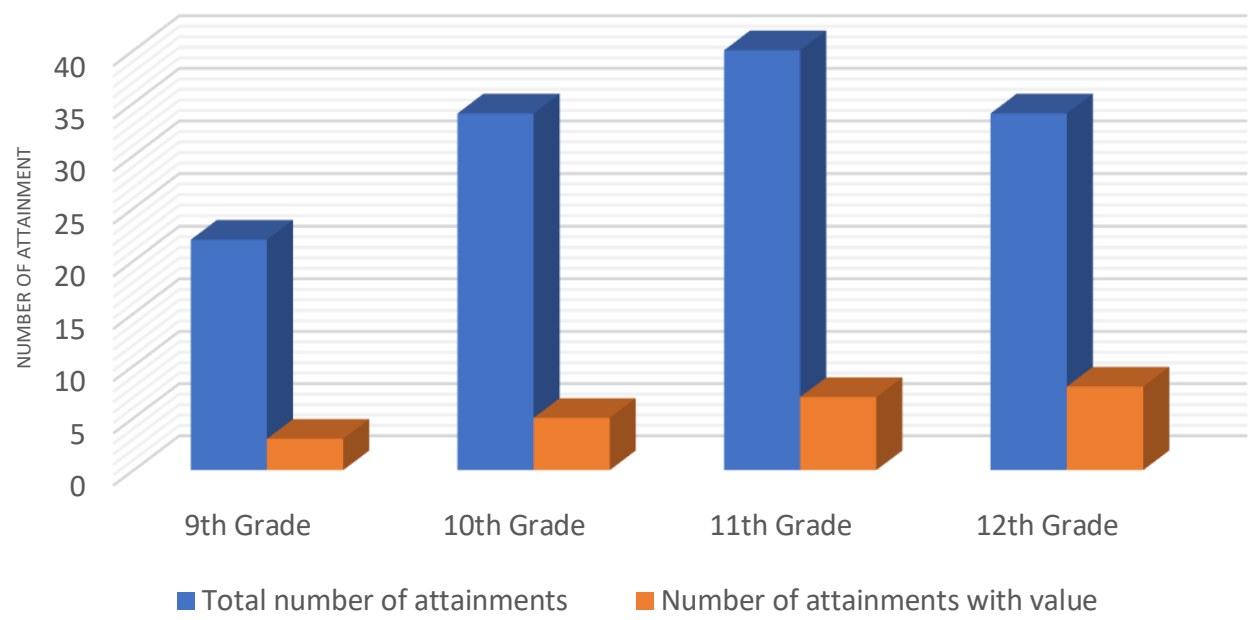

Figure 4. Number of attainments GCC with value relative to grade levels in 2017 (MoNE, 2017)

Looking at what values are included in the 2017 GCC by grade level, it is value noting that not all ten values are included at each grade level. The only value included in the curriculum at all nine, ten, eleventh and twelfth grade levels is patriotism (Figure 5). Looking at the distribution of the other 9 root values according to class levels, the value of fairness is 11 ; the value of love for nature is 9 , 11 and 12; the value of friendship is 10 ; the value of honesty is 12 ; the value of patience is 10 , the value of respect is 10 and 11 ; the value of responsibility is 10 and 11 ; the value of self-control is 9,11 and 12; the value of benevolence appears to be only at the tenth grade level (Figure 5). Seventeen of the 31 relationship of the geography of the total value in the curriculum is selective justice and honesty eleventh and twelfth grade levels that take place at a twelfth-grade level, as well as the value of the curriculum to be placed at state is emerging as a negative in terms of values education.

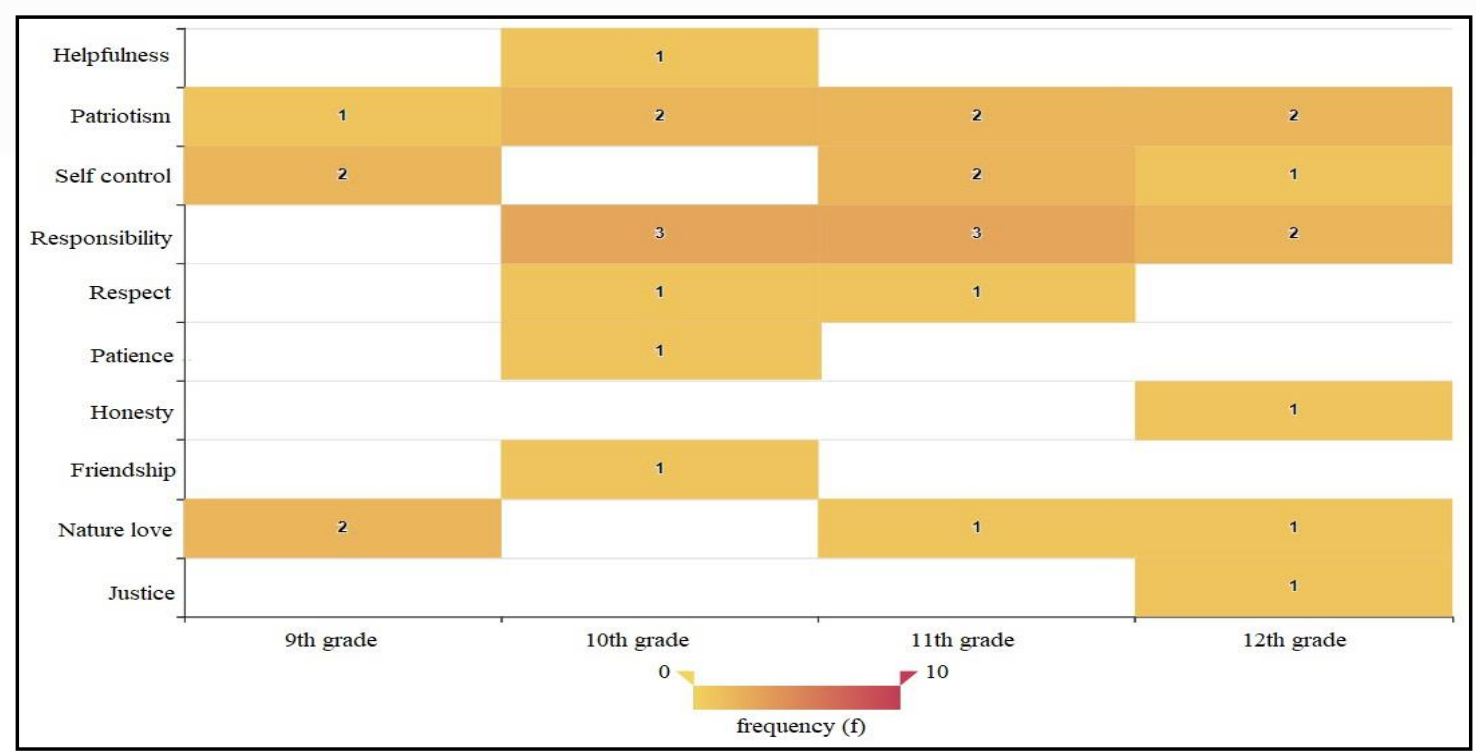

Figure 5. Value-grade Level Relationship at 2017 GCC (MoNE, 2017) 
Geography Curriculum in 2018. 2017 the GCC underwent a small-scale overhaul in 2018, which reflected the value size of the curriculum. Ten values included in the 2017 GCC were also included in the 2018 GCC, but attitudes and behaviors related to values included in the 2017 GCC were not included in the 2018 GCC (table 12-11). However, the 10 values in question were referred to as root values in the 2018 GCC (MoNE, 2018). In the curriculum, it is stated that these root values also contain sub-values within themselves. Respect as a root value for example, it includes sub-values such as respect for differences, respect for human rights, respect for social rules, and respect for beliefs. In this direction, it is stated that root values in the curriculum should be considered together with sub-values and other root values that are not included in the curriculum. (MoNE, 2018). In this context, it can be said that there is no value limitation in the 2018 GCC and that the curriculum has a flexible structure on value.

Another change in values with the 2018 GCC was in the value-attainment Relationship. Accordingly, the value of patience at the 2017 GCC is "10.4.4. Describes disaster protection methods " this relationship was removed in the 2018 GCC when it was relationship with acquisition (table 13). But since the value of patience is not relationship with another attainment, it was included in the curriculum as the only value that was not relationship with value-attainment. In this context, as in the $2017 \mathrm{GCC}$, the correlation of values by class, unit and attainments does not show a homogeneous distribution in the 2018 GCC (Figures 3, 4, 5). As a result, with the exception of these three minor changes, the values education dimension of the 2018 GCC is the same as the 2017 GCC.

\section{Result and Discussion}

School life is a very important period in the acquisition process of values that continue from birth to the end of our lives. Geography as a school course contributes to citizenship on a local and global scale through correct decision-making on environmental issues, critical thinking about the relationship between citizenship and responsibility, developing a sense of place, clarifying values according to ideas about people and countries (Stoltman, 2006). For this reason, GCC's prepared both in Turkey and in different countries include open or confidential values education. But looking at the field, it seems that research on values education in geographical education research in Turkey is extremely limited. (Çifçi \& Ünaldı, 2014; Katılmış \& Balcı, 2017; Değirmenci, 2018; Aydın \& Yaşar, 2020). There is only one research on GCC and value education (Değirmenci, 2018). This situation is seen as an important deficiency from the point of view of the field. However, values are inherent in geographical education (Wiegand, 1986). As a matter of fact, the declarations and declarations published by IGU-CGE strongly emphasize values and values education (IGU-CGE, 1992; IGU-CGE, 2000; IGU-CGE, 2007; IGU-CGE, 2016).

Looking at the development of values education in GCC in Turkey in the process from the Republic to the present day, three periods are value noting: 1924-1971, 1971-2005 and 2005-2021. There is no content on the values in the GCCS'simplemented in the first period, 1924-1971. Looking at the period 1971- 
2005 , which is the second semester, it is seen that the GCC's applied during this period are implicitly emphasized in the general teaching purposes. Looking at the period after 2005, the values in the GCC's applied during this period are included under the heading "values", not only within the general objectives of the curriculum, but also as a curriculum element. In this context, the place of values in the GCC appears to be based on the 1971 GCC much earlier than the 2005 GCC, albeit implicitly.

Table 14

Values in GCC's from the Republic to the Present

$\begin{array}{ll}\text { Values in GCC's } & \frac{1924}{1927} \\ \text { Applied in the Period } & \frac{1938}{1940} \text { GCC's implemented during this period do not contain any } \\ \text { 1924-1971 } & \frac{1942}{1957}\end{array}$

Saving, love of nature, making efforts to solve the problems of the country and the world, taking 1971 responsibility for cultural and economic development, helping with different cultures, understanding peace and

Values implicitly emphasized in the General Teaching purposes of GCC's implemented in the period 1971-2005 cultural diversity

Patriotism, human love, striving for country and world problems, responsibility for cultural and economic

1973 development, understanding cultural diversity, helping with different cultures, peace, protecting natural and cultural heritage/resources, responsibility

1983 Patriotism, human love, saving, love of nature, helping 1992 with different cultures, peace, protecting natural and cultural heritage / resources

\begin{tabular}{|c|c|c|}
\hline \multirow{5}{*}{$\begin{array}{l}\text { Values in GCC's } \\
\text { Applied in the Period } \\
\text { 2005-2018 }\end{array}$} & 2005 & \multirow{4}{*}{$\begin{array}{l}\text { Respect, love, responsibility, patriotism, solidarity, } \\
\text { tolerance, science, sensitivity, peace, esthetics }\end{array}$} \\
\hline & 2010 & \\
\hline & 2011 & \\
\hline & 2014 & \\
\hline & 2017 & $\begin{array}{l}\text { Respect, love, responsibility, patriotism, justic } \\
\text { friendship, honesty, patience, self-control, helpfulness }\end{array}$ \\
\hline
\end{tabular}

In the period from 1971 to the present, many different values are included in the GCCS (table 14). In particular, the values implicitly emphasized in the general teaching objectives of the 1971 and 1973 GCCS in the period 1972-2005 appear to be significantly similar to the values contained in the declarations and declarations issued by IGU-CGE between 1992-2016 (Table 2). But this positive situation was interrupted by the 1982 GCC. The military coup of 12 September 1980 can be seen as the reason for this situation. As a matter of fact, Kaya and Önal (2019) state that the effects of the September 12 coup were seen in Geography textbooks of the period with the 1982 and 1983 GCC. In the general teaching purposes of the 1982 GCC, which was implemented after the military coup of September 12, 1980, only the value of patriotism was included in the $1983 \mathrm{GCC}$, and in the process up to the 2005 GCC, the emphasis on patriotism was more predominantly than other others (table 
14). Therefore, it can be said that the values of GCCS were more in the direction of citizenship education during this period.

In terms of values education, the 2005 GCC marks the second milestone after the 1971 GCC. Because with the 2005 GCC, values were included as a curriculum component for the first time and 10 values were included under the heading "values and attitudes" (table 12). However, these values are relationship with the curriculum content is not of values in the curriculum as attainments in size in the process, students did not provide sufficient explanation of how-to attainment how to. As a matter of fact, the findings of Çifçi and Ünaldı (2014) research on the views of geography teachers on values education also support this situation. According to the research in question, teachers believe that explanations for values education at GCC are not adequately included. Following the 2005 GCC, the current negative situation at the 2005 GCC continued in the 2010, 2011 and 2014 GCC, and there was no change in terms of values education.

The 2017 GCC is the third milestone in terms of values education. Because for the first time with the 2017 GCC, the values included in the GCC are relationship with class level, unit and achievements (Şahin, 2018). In this way, the values became much more visible during the implementation process of the curriculum than in the 2005 GCC. In this context, it is seen that values education is more at the forefront in the 2017 GCC than in previous curriculums. The findings of the study conducted by Değirmenci (2018), which examined the 2017 GCC in terms of values education, also support this situation. In the 2017 GCC, linking values together with geographical skills to unit and achievements will allow teachers and textbook authors who are Curriculum practitioners to place values more effectively in the teaching process.

But the relationship of values with achievements in the curriculum was only in the form of what value will be considered in the relevant acquisition. However, in the curriculum, the Relationship of values with classes, units, and attainments also does not show a homogeneous distribution. Another negative situation is that the statements contained in the introduction section of the 2017 GCC under the heading "our values" are not sufficient, as in the 2005 GCC. This also coincides with Değirmenci's (2018) research findings. Under this heading, it is explained only why the values are important and what the values included in the curriculum are. However, it is considered an important deficiency that the values determined in the curriculum are not included in what size and how to relate to the attainments made in the relationship.

A small-scale revision was carried out in the 2017 GCC very soon and the 2018 GCC was put into practice from the 2018-2019 academic year. The revision in question was partly reflected in the 2018 GCC's values education dimension. Accordingly, the 10 values included in the 2017 GCC were called "root values" in the 2018 GCC, attitudes and behaviors given to values were removed from the curriculum, and the value of patience was not relationship with any attainments. The negativity regarding values education in the 2017 GCC mentioned above appears to have continued in the 2018 GCC as well. Accordingly, the 2018 GCC does not include adequate explanations for values education, as in 2005 and 2017 GCC. In this context, it can be concluded that the same problem has persisted since the 
2005 GCC. Another negative situation in 2018 GCC value-sufficient and does not have a uniform distribution and relationship acquisition unit (Figure 6) Değirmenci (2018) have reached the same conclusion in GCC for GCC 20172018 indicate that no change has been made for resolving these difficulties. In the $2018 \mathrm{GCC}$, the unit with the most value relationships are" natural systems". (Figure 6) the destructive destruction of natural systems as a negative result of human-nature interaction also leads to the fact that the transfer of value to natural systems is more at the forefront of the nature of geographical education. In this context, it is not surprising that the unit with the most value is natural systems. But only four value relationships have been made for the "global environment: regions and countries" unit, all of which are at the eleventh and twelfth class levels. At these grade levels, the geography course is not mandatory.

However, this unit includes achievements including economic, cultural, strategic and geopolitical dimensions, global relations and their consequences, countries and regions that have come to the fore with their important characteristics, organizations with global influence, geopolitical tensions and conflict areas (MoNE, 2018). For this reason, it is possible to make many value relationships within the scope of the" global environment: regions and countries "unit, especially in order to raise awareness of global citizenship. The same applies to the" environment and society" unit. Only 5 value relationships are included in the" environment and Society" unit. This unit includes achievements related to the use of natural resources, natural disasters, environmental problems, Management and planning, and environmental change.

The issues involved in these attainments are crucial to the sustainability of our planet, both locally and globally. Environmental problems are seen on all spatial scales and are complex and value-laden at the same time. In order for these problems to be solved, responsibility must be taken by each individual. In this context, environmental and geographical education also promotes effective citizenship, as well as the development of environmental awareness and spatial thinking skills (Kailova, 2013). For this reason, it would be appropriate to include more value relationships within the" environment and society " unit. 
SSahin, B. (2021). The Development of Values Education in the Turkish High School Geography....

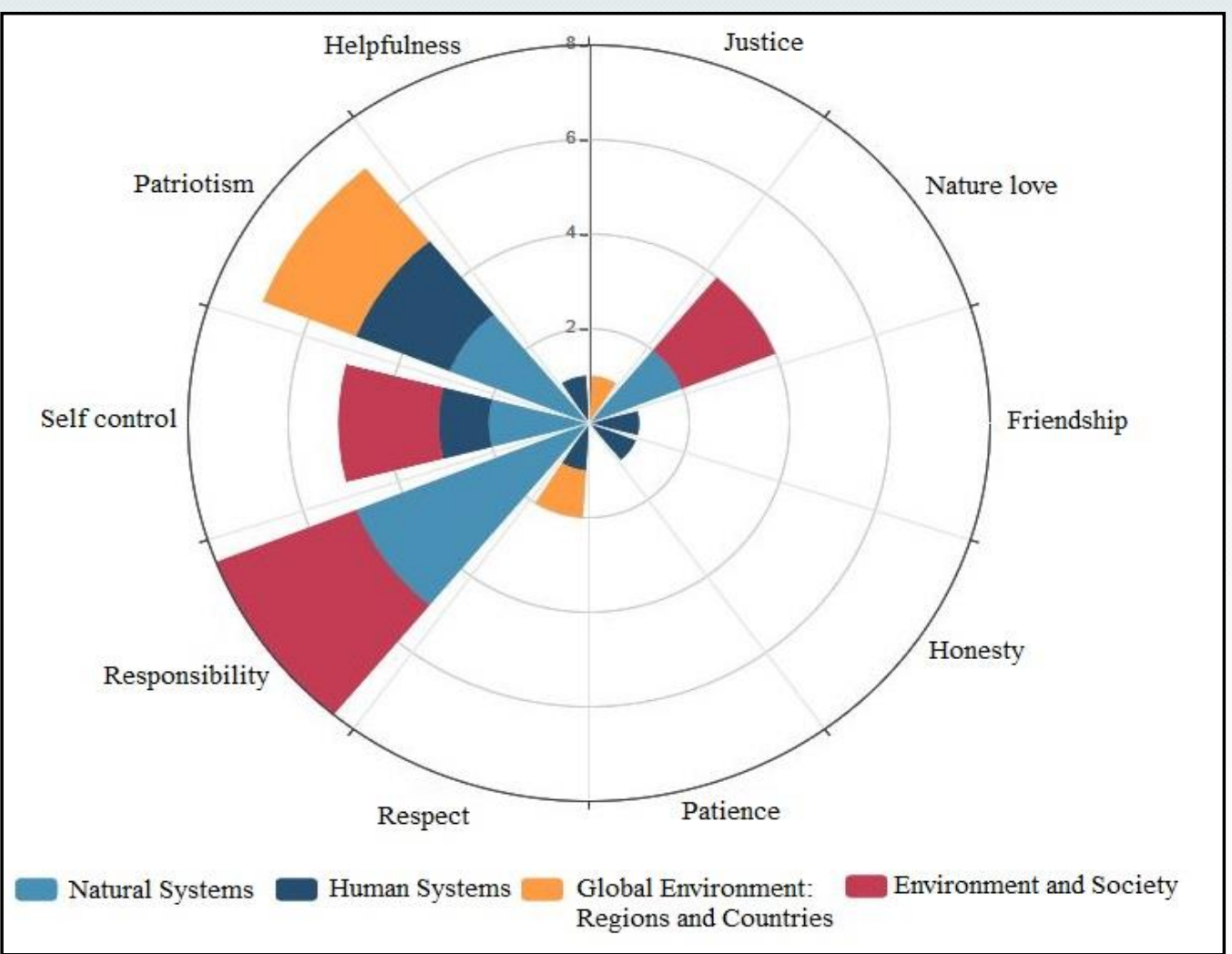

Figure 6. GCC's value-unit Relationship 2018

Looking at the correlation of the values contained in the 2018 GCC with the grade level, it is attainment seen that there is no homogeneous distribution (Figure 5). The most value relationships in the curriculum were made at the eleventh and twelfth grade levels. As a reason for this situation, it can be seen that the number of achievements at the eleventh and twelfth grade levels is high. But at these grade levels, the geography course is not mandatory and should be chosen. For this reason, this situation will also negatively affect the transfer of value. Therefore, in the event of an update or renewal of the GCC, it would be appropriate for the value Relationship to be broader at grade levels, where the geography course is compulsory.

As a result, it can be said that in the last half century, GCC's have shown slow but continuous development in terms of values education. But how this development process is reflected in the educational process is a separate research topic. In this study, GCC's applied in the period from the republic to the present day were examined with the dimension of value education. Taking into account the periods mentioned above, the study of textbooks taught during these periods with the dimension of values is a separate research topic and will make an important contribution to the field.

\section{Suggestions}

The important problem in terms of values education in the 2018 GCC, which is currently being implemented, is that the explanations under the title "values" in the curriculum are extremely limited and insufficient, as in the 2005 GCC and subsequent curriculums. In this context, if the GCC is updated or renewed in the 
future, adequate explanations should be given to guide the curriculum practitioners in the values education section in the introduction of the curriculum. Because the strategies used by teachers in the classroom are extremely important in the value development of students (Ferreira, 2000). However, undergraduate education in values education in the GCC as well as inadequate explanations for "character and value education" course in values education teachers who did not take effective learning and teaching strategies is difficult. Because both the way the selected value content is handled in, the class and its context with the selected acquisition are extremely important (Lambert, 1999).

For this reason, examples of activities should be included in GCC about how values will be acquired by following a path in geographical education, how to transfer values with geographical skills such as geographical inquiry skills. The detailed description and activities in question can be given in a curriculum guide or in an internet portal to be prepared, as in different countries, even if they are not in the curriculum. For example, the Australian government, education, employment and Workplace Relations department (Australian Government, Department of education, employment and Workplace Relations) National framework for values education in the set value 9 (interest and compassion, do your best, to be fair, freedom, accuracy and reliability, honesty, respect, responsibility, understanding, tolerance and participation) has provided a rich pool for the content on this website (Zengin, 2017). This content pool includes various educational materials for values education, such as various resources, lesson plans and activities (Australian Government Department of Education, t.y.). A similar practice can make GCC more effective in terms of values education in Turkey.

\section{References}

Akbaş, 0. (2006). MEB ilköğretim sosyal bilgiler dersi 6.sınıf öğretim curriculumı ve kılavuzu değer öğretiminde yeni yaklaşımlar. Ankara: Milli Eğitim Basımevi.

Artvinli, E., \& Kaya, N. (2010). 1992 International Charter on Geographical Education and its reflections in Turkey. Marmara Coğrafya Dergisi, (22), 93-127. Retrieved from https://dergipark.org.tr/tr/download/article-file/3214

Artvinli, E. (2020). Coğrafi sorgulama becerisi. In Ç.Ö. Demirbaş (Ed.), Coğrafi beceriler (1st ed.). Ankara: Nobel Yayın Dağitim.

Aslan, S., \& Aybek, B. (2019). Uygulama Örnekleriyle Çokkültürlü Eğitim ve Değerler Eğitimi. Ankara: Anı Yayıncılık.

Australian Government Department of Education, (n.d.). Values Education for Australian Schooling. Retrieved from http://www.curriculum.edu.au/values/values_ homepage,8655.html

Aydın, H., \& Yaşar, O. (2020). Comparison of geography textbooks written according to 2005 and 2017 geography lesson curriculum in terms of values education. Journal of Social and Humanities Sciences Research, 7(60), 2826-2842. http://dx.doi.org/10.26450 /jshsr.2099

Beldağ, A. (2019). Öğretim curriculumlarında değerler eğitimi. In S. Z. Genç \& A. Beldağ (Eds.), Karakter ve değer eğitimi farklı bakışlar örnek etkinlikler (pp. 135-144). Ankara: Pegem Akademi.

Buttimer, A. (1974). Values in geography (Research Report No: 24). Washington: 
SSahin, B. (2021). The Development of Values Education in the Turkish High School Geography....

Relationship of American Geographers Commission on College Geography.

Creswell, J. W. (2013). Research design: qualitative, quantitative, and mixed methods approaches (4th ed.). SAGE Publications.

Çalık, M., \& Sözbilir, M. (2014). Parameters of content analysis. Education and Science, 39(174), 33-38. https://doi.org/10.15390/EB.2014.3412

Çifçi, T., \& Ünald, Ü. E. (2014). Remarks and views of geogaphy teachers on current situation of value education. Zeitschrift Für Die Welt Der Türken/Journal of World of Turks, 6(2), 81-99. Retrieved from http://www.dieweltdertuerken.org/index.php /ZfWT/article/view/613/613

Değirmenci, Y. (2018). Values in geography teaching curriculum. Journal of History Culture and Art Research, 7(1), 429-450. https://doi.org/10.7596/taksad.v7i1.1311

Demircioğlu, İ. H., \& Tokdemir, M. A. (2008). The role of history education in the process of construcing values: aims, functions and content. Değerler Eğitimi Dergisi, 6(15), 6988. Retrieved from https://ded.dem.org.tr/gorsel/pdf/ded-15-makale-3.pdf

Demirhan İșcan, C. (2019). Değerler eğitiminde temel kavramlar. In F. Ersoy \& P. Ünüvar (Eds.), Karakter ve değerler eğitimi (pp. 31-50). Ankara: Anı Yayıncllık.

Edynbry, D., Hellyer, M. J., \& Turner, M. (1977). Attitudes and values in geography teaching. Geography, 62(3), 205-208. Retrieved from: https://www.jstor.org/stable /40568734

Ferreira, M. M. M. (2000). Values in the Portuguese geography national curriculum documents for the seventh and ninth years (ages 12 and 14). International Research in Geographical and Environmental Education, 9(1), 75-78. http://dx.doi.org/10. 1080/ 10382040008667636

Fien, J. (1981). Values probing: An integrated approach to values education in geography. Journal of Geography, 80(1), 19-22. https://doi.org/10.1080/00221348108980223

Fien, J. (1996). Teaching to care: A case for commitment in teaching environmental values. In R. Gerber \& J. Lidstone (Eds.), Developments and directions in geographical education (pp. 77-91). Channel View Publications.

Fu, J. H. Y., \& Chiu, C. Y. (2007). Local culture's responses to globalization: Exemplary persons and their attendant values. Journal of Cross-Cultural Psychology, 38(5), 636653. https://doi.org/10.1080/09585176.2011.601682

Geçit, Y. (2008). A work deals with on the curriculummes of republic term lycee geographical education. Marmara Coğrafya Dergisi, (18), 149-178. Retrieved from: https://dergipark.org.tr/tr/pub/marucog/issue/465/3750

Genç, S. Z. (2019). Değerler: temel kavramlar. In S. Z. Genç \& A. Beldağ (Eds.), Karakter ve değer eğitimi farklı bakışlar örnek etkinlikler (pp. 3-15). Ankara: Pegem Akademi.

Hernando, A. (1998). Values in geographical education and teacher training. International Research in Geographical and Environmental Education, 7(2), 168-174. https://doi.org/10.1080/10382049808667571

Hong, J. E. (2018). Critical citizenship education through geography. International Journal of Geospatial and Environmental Research, 5(3). Retrieved from https://dc.uwm.edu /ijger/vol5/iss3/7

Hopwood, N. (2008). Values in geographic education: The challenge of attending to learners' perspectives. Oxford Review of Education, 34(5), 589-608. https://doi.org/10.1080/ 03054980701768766 
IGU-CGE. (1992). 1992 International charter on geographical education. International Geographical Union, Commission on Geographical Education. Retrieved from http://www.igu-cge.org/wp-content/uploads/2018/02/1.-English.pdf

IGU-CGE. (2000). 2000 International declaration on geographical education for cultural diversity. International Geographical Union, Commission on Geographical Education. Retrieved from https://www.igu-cge.org/2000-declaration/

IGU-CGE. (2007). 2007 Lucerne declaration on geographical education for sustainable development. International Geographical Union, Commission on Geographical Education. Retrieved from https://www.igu-cge.org/2007-declaration/

IGU-CGE. (2016). 2016 International charter on geographical education. International Geographical Union, Commission on Geographical Education. Retrieved from http://www.igucge.org/wpcontent/uploads/2019/03/IGU_2016_eng_ver25Feb2019.pdf

Kailova, T. (2013). İnternational Collaboration in the field of environmental and geographical education. In R. Gerber (Ed.), International Handbook on Geographical Education (pp. 191-201). Springer Science \& Business Media.

Kalita, K. (2015). Need of value education and teacher's role. International Journal of Social Science and Humanities Research, 3(4), 566-571.

Karabağ, S., \& Şahin, S. (2007). Coğrafya Dersi Öğretim Curriculumı (2005). In S. Karabağ \& S. Şahin (Eds.), Kuram ve Uygulamada Coğrafya Eğitimi (pp. 55-74). Ankara: Gazi Kitapevi.

Katılmış, A. (2017). Values education as perceived by social studies teachers in objective and practice dimensions. Educational Sciences: Theory and Practice, 17(4), 12311254. https://doi.org/10.12738/estp.2017.4.0570

Katılmış, A., \& Balcı, A. (2017). The investigation of geography teacher candidates opinions' towards values education. Marmara Coğrafya Dergisi, (35), 1-12. https://doi.org $/ 10.14781 / \operatorname{mcd} .291011$

Kaya, N., \& Önal, H. (2019). 12 Eylül 1980 Askeri darbesinin coğrafya öğretim curriculumı ve ders kitaplarına yansıması. Milli Ĕgitim Dergisi, 48(223), 283-298. Retrieved from: https://dergipark.org.tr/tr/pub/milliegitim/issue/48112/609215

Knapp, C. E. (1972). Attitudes and values in environmental education. The journal of environmental education, 3(4), 26-29. http://www.tandfonline.com/action/ showCitFormats?doi=10.1080/00958964.1972.10801677

Kurtdede Fidan, N. (2019). Karakter ve değerler eğitiminde yararlanılan yöntem ve teknikler. In F. Ersoy \& P. Ünüvar (Eds.), Karakter ve değer eğitimi (pp. 215-239). Ankara: Anı Yayıncılık.

Lam, C. C. (1993). Values education in secondary school geography in Guangzhou. International Research in Geographical \& Environmental Education, 2(2), 52-63. https://doi.org/10.1080/10382046.1993.9964910

Lambert, D. (1999). Geography and moral education in a super complex world: the significance of values education and some remaining dilemmas. Ethics, Place and Environment, 2(1), 5-18. https://doi.org/10.1080/13668799908573652

Lambert, D., \& Balderstone, D. (2002). Learning to teach geography in the secondary school: A companion to school experience. London: Routledge.

Machon, P., \& Walkington, H. (2000). Citizenship: the role of geography. In A. Kent (Ed.), Reflective practice in geography teaching. London: Paul Chapman. 
SSahin, B. (2021). The Development of Values Education in the Turkish High School Geography....

Ministry of National Education. (1971). 1971 Geography Curriculum, Ankara.

Ministry of National Education. (1973). 1973 Geography Curriculum, Ankara.

Ministry of National Education. (1982). 1982 Geography Curriculum, Ankara.

Ministry of National Education. (1983). 1983 Geography Curriculum, Ankara.

Ministry of National Education. (1992). 1992 Geography Curriculum, Ankara.

Ministry of National Education. (2005). 2005 Geography Curriculum, Ankara.

Ministry of National Education. (2010). 2010 Geography Curriculum, Ankara.

Ministry of National Education. (2011). 2011 Geography Curriculum, Ankara.

Ministry of National Education. (2014). 2014 Geography Curriculum, Ankara.

Ministry of National Education. (2017). 2017 Geography Curriculum, Ankara.

Ministry of National Education. (2018). 2018 Geography Curriculum, Ankara.

Ministry of Education, Singapore. (2018). Singapore Curriculum Philosophy. Retrieved from: Ministry of Education Singapore, https://www.moe.gov.sg/about/singaporeteaching-practice/singapore-curriculum-philosophy

The Organisation for Economic Co-operation and Development. (2019). OECD Future ofEducation and Skills 2030 Conceptual learning framework. Retrieved from http://www.oecd.org/education/2030-project/teaching-andlearning/learning/attitudes-andvalues/Attitudes_and_Values_for_2030_concept_note.pdf

Rawling, E. (2008). Planning your key stage 3 curriculum. Teaching Geography, 33(3), 114119.

Roberts, M. (2003). Learning through enquiry: making sense of geography in the key stage 3 classroom. Geographical Relationship.

Rokeach, M. (1973). The nature of human values. Newyork: Free press.

Şahin, B. (2019). A comparative assessment towards the geography course curriculum 2005 and 2018. Türk Eğitim Bilimleri Dergisi, 17(1), 81-102.

Shukla, R. P. (2004). Value education and human rights. New Delhi: Sarup \& Sons.

Slater, F. (1994). Education through geography: knowledge, understanding, values and culture. Geography, 79(2), 147-163.

Slater, F. (2001). Values and values education in the geography curriculum in relation to concepts of citizenship. In David Lambert \& P. Machon (Eds.), Citizenship through secondary geography (pp. 42-67). Routledge Falmer.

Stoltman, J. P. (2006). Turning points in geographic education. In J. Lidstone \& M. Williams (Eds.), Geographical education in a changing world: past experience, current trends and future challenges (pp. 23-38). Netherlands: Springer.

Board of Education. (2017). Press release of the Board of Education, dated 18 July 2017. Retrieved from http://ttkb.meb.gov.tr/meb_iys_dosyalar/2017_07/18160003 _basin_aciklamasi-curriculum.pdf

Ulusoy, K. (2017). Hayat bilgisi dersinde değerler ve değerler eğitimi. In B. Tay (Ed.), Etkinlik örnekleriyle hayat bilgisi öğretimi (pp. 323-351). Ankara: Pegem Akademi.

Ulusoy, K., \& Dilmaç, B. (2018). Değerler Eğitimi. Ankara: Pegem Akademi.

United Nations International Children's Emergency Fund. (2019). Every Child Learns 
UNICEF Education Strategy 2019-2030. Retrieved from https:// www.unicef.org/media/59856/file/UNICEF-education-strategy-2019-2030.pdf

Venkataiah, N. (2002). Research in value education. New Delhi: APH Publishing Corporation.

Venu, V. P. (2018). Importance of value education. International Journal of Innovative Research \& Studies, 8(1), 114-123.

Wiegand, P. (1986). Values in geographical education. In P. Tomlinson \& M. Quinton (Eds.), Values across the curriculum. New York: Routledge.

Yarar Kaptan, S. (2019). Kararkter ve değer eğitiminde yaklaşımlar, yöntemler ve teknikler. In S. Z. Genç \& A. Beldağ (Eds.), Karakter ve değer eğitimi farklı bakışlar örnek etkinlikler (pp. 146-168). Ankara: Pegem Akademi.

Yiğittir, S., \& Kaymakcl, S. (2012). Examination of activities in primary school social studies curriculum guides ( 4 th to 7 th grades) in terms of value education approaches. Ahi Evran Üniversitesi Kırșehir Eğitim Fakültesi Dergisi, 13(2), 49-73. Retrieved from: https://dergipark.org.tr/tr/pub/kefad/issue/59489/854976

Yıldırım, A., \& Şimşek, H. (2016). Sosyal Bilimlerde Nitel Araştırma Yöntemleri. Ankara: Seçkin Yayınları.

Zengin, M. (2017). Values education in Australian schools as a model case. The Journal of International Social Research, 10(52), 866-883. http://dx.doi.org/10.17719/jisr. 2017.1943

\section{Biographical Statement}

Bahaddin ŞAHIN is a geography teacher in the Board of Education, Ministry of National Education in Turkey. His areas of interest include the geographical education, map literacy and thematic cartography. 